This is a self-archived version of an original article. This version may differ from the original in pagination and typographic details.

Author(s): Kleidosty, Jeremy

Title: Māwardī and Machiavelli : Reflections on Power in their Mirrors for Princes

Year: 2018

Version: Published version

Copyright: (c) 2018 by University of Hawai'i Press

Rights: In Copyright

Rights url: http://rightsstatements.org/page/lnC/1.0/?language=en

Please cite the original version:

Kleidosty, J. (2018). Māwardī and Machiavelli : Reflections on Power in their Mirrors for Princes. Philosophy East and West, 68(3), 721-736. https://doi.org/10.1353/pew.2018.0070 


\title{
MĀWARDĪ AND MACHIAVELLI: REFLECTIONS ON POWER IN THEIR MIRRORS FOR PRINCES
}

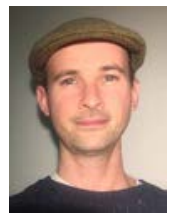

\author{
Jeremy Kleidosty \\ Department of Social Sciences and Philosophy, \\ University of Jyväskylä \\ jeremy.s.kleidosty@jyu.fi
}

"First, he must guard the faith."

Al Māwardī, The Ordinances of Government

"And it must be understood that a ruler ... cannot always act in ways that are considered good because, in order to maintain his power, he is often forced to act treacherously, ruthlessly or inhumanely, and disregard the precepts of religion."

Machiavelli, The Prince

Despite their apparently contradictory views on the role of religion in statecraft, and despite being separated by 500 years of history and thousands of miles of geography, al-Māwardī (972-1058 C.E.) and Machiavelli (1469-1527 C.E.) both approach the relationship of power and persuasion in an unapologetically direct fashion that shocked their contemporaries and continues to challenge their readers to this day. Following brief biographical profiles, this paper will interrogate their respective philosophies and the way in which their highly unstable social settings and their rather more stable religious traditions were woven into their thought as seen in two of their key texts.

Māwardī's The Ordinances of Government is infused with a concern for the derivation, use, and delegation of power. Māwardī's conception of the institutional nature of the Caliphate gives it a preeminent position in his formulation of power. Thus, he emphasizes the Caliphate's continuation as the first condition for any government to claim the mantle of Islam and be "legal" in the sense of complying with the eternal dictates of sharīa. This timeless rule of law can support and sustain the multitude of constantly shifting regulations and political actors in any real state. Furthermore, there is an unrelenting concern with the practical and mundane affairs of the daily business of governing that permeates his writing, constantly connecting transcendent truth to the fine details of society and how it does business, entertains itself, defends itself, and cares for its least fortunate.

This style of literature, in which a sage offers advice to a political benefactor, is generally called Mirror for Princes literature. As with any mirror, the work of Māwardī and Machiavelli shares a number of features, yet proceeds on nearly opposite (or mirror-image) premises. Machiavelli takes a far less institutionalized view of power and instead views it in terms of individualized princely attributes and actions. The Prince is not titled 
"The Principality" or "The Principate," which would have denoted a concern with the larger society or the prince as an institutional figure. Rather, it is genuinely directed at providing the honest political education that he believes the pursuit and exercise of power requires. His preoccupation with virtue, for example, is indicative of his incarnate and personified representation of power, whereas his discussion of Fortuna reveals his acceptance of the prominent role random luck plays in gaining and maintaining power.

Though sharing views that can be characterized as realpolitik, Māwardī and Machiavelli's divergent approaches to power make them an opposite yet harmonious pair. Ultimately, this paper seeks to question whether these thinkers, who continue to command widespread engagement within their respective traditions, provide useful insights into how new political and ethical norms might be derived in pluralist contexts.

\section{Māwardī's Mirror-Reflections of Institutionalism in Personified Power}

One of the most common critiques made against 'Islamic' regimes past and present is that they lack a mechanism for restraining the power of the state or ruler, and that they legitimize virtually any exercise of power so long as they maintain a veneer of religiosity. This critique has been extended even to claiming that Islamic regimes are in some way reflective of a civilizational clash of cultures. For example, one recent monograph makes the following provocative pronouncement:

Comparison between Islam and the West suggests that the overall religious or cultural mindset is more important in the long term than specific doctrines (such as absolute monarchy or the rule of law). Western and eastern Christians drew some wildly different political conclusions from the same sacred texts. Some in the Islamic world and in the West adopted quasi-rationalist views about how one knows something to be true, which differed radically from those of some of their own co-religionists. But both philosophy and the appeal to reason as an independent guide died out in the Muslim world; while in the West they became established and respectable pursuits and methods of argument (Chapter 6). This was one underlying cause, though not the only cause, for political thought being so different in the two cultures. ${ }^{1}$

Aside from the obvious difficulty in assigning the label of "Muslim World" to states which were often multifaith, multicultural, and relatively tolerant of these differences, this quote illustrates the persistence of the perception that somehow a Muslim or Islamic state, especially if it explicitly appeals to shari ${ }^{`}$ a and thus is based in religious faith, must somehow be irrational. An examination of Māwardī's text The Ordinances of Government quickly demonstrates however, that even in times which could rightly be labeled a nadir for genuine unity within the House of Islam, with fighting between rival claimants to the caliphate and competing Islamic empires 
constantly at war, the desire to implement sharīa is approached in a methodical, even bureaucratic way that is easily recognizable as a form of highly institutionalized government in which the identity and character of individuals in power is far less central than the protection of the institutions in which they serve.

Born in 974 A.D. and living until 1058 A.D., he was the son of a rosewater merchant in Basra during the reign of the Abbasid Caliphate in Baghdad. His life was one immersed in the power struggles of this time, with near constant political upheaval arguably wielding a particularly strong influence upon his thought. The following assessment of his work will discuss Māwardī's conception of the institutional nature of the Caliphate and its preeminent position in his formulation of power, making note of his emphasis on the need for the Caliphate to continue in order for any government to claim the mantle of Islam and be "legal," in the sense of complying with the eternal dictates of sharī a.

Although Māwardī's The Ordinances of Government predates elected parliaments by hundreds of years, it nonetheless shows a conscientious concern for the public good. Its emphasis on proper management of institutions bears a strong resemblance to the way organizations such as the European Union and United Nations are run. Likewise, the centrality of competing political groups rather than of charismatic individuals also reflects the way that most parliamentary democracies function today. Thus, at least in terms of Māwardī's formulation of the Muslim state, it would seem that rationality and institutional preservation are far more central to his vision of government than despotic power. This point will be further illustrated by a brief examination of the functions he considers most essential to government in general, and Islamic government in the institution of the caliphate in particular. ${ }^{2}$

The ten public duties of the Caliph are delineated as follows:

First, he must guard the faith, upholding its established sources and the consensus of the nation's ancestors, arguing with emerging heretics or suspicious dissenters ... administering to them the legal penalties, so that the faith should remain pristine... Second, he must enforce law between disputing parties ... Third, he must protect the country and the household ... . Fourth, he must dispense the legal punishments ... Fifth, he must strengthen border posts (by both equipment and soldiers) ... Sixth, he must fight those who resist the supremacy of Islam ... until they convert or sign a treaty of subjection, so that God's claim to have a faith superior to any other is established ... Seventh, he must collect the legal taxes and alms ... Eighth, he has to estimate payments and allocations ... and pay them neither before nor after the appointed time... Ninth, he must appoint men who are reliable and sincere and of good counsel to ... take care of the funds he charges them with in order to ensure efficiency ... Tenth, he has personally to oversee matters and study the conditions of the people in order to manage public policy 
and guard the faith instead of relying on delegation of authority while he is preoccupied with pleasure or worship ... ${ }^{3}$

Notice that the first and most important role of the caliph is to "guard the faith." Although it does not specify in itself the nature of how his authority can be exercised, it clearly locates its source in the divine. Indeed, his authority is put into effect and affirmed by protecting the observance of sacred law in the midst of the worldly, day-to-day affairs of the state.

Duties two through five are essentially law and order related duties, which would commonly be considered the purview of the political state. They involve various forms of rendering judgment, presumably through a system of courts, administering sanctions and enforcing domestic law, and protecting one's subjects from the threat of both invasion and civil unrest. This division of duties between those which are religious, requiring knowledge and independent reasoning, or ijtihad, in the application of religious law, and the more standard state functions of law enforcement and defense, show that Māwardī was well aware that sharī‘a had to be complemented with additional government regulation for the effective running of the state. ${ }^{4}$

The sixth point comes back to religious duties, being a statement of a kind of jihad and a reminder that non-Muslims will be subject to dhimmi (protected) status and its attendant jizya (poll tax). Generally, the idea of these practice of extra taxation and restricted social roles are meant to provide monetary and political motivation, a type of coercive soft power, for most people to embrace Islam, leading to an ever-increasing religious unity within the state.

Points seven through nine demonstrate that much of the business of the state is in fact inseparably religious and secular. The collection of alms (zakat), for instance, is a requirement of all Muslims. However, the need to avoid corruption and to ensure the best possible use of this money for the public good is both a matter of statecraft (siyasa) and sharī́a.

Out of all the caliphal duties, the tenth is perhaps the one with the most resonance in this comparative analysis. The Caliph has, "personally to oversee matters and study the conditions of the people in order to manage public policy and guard the faith instead of relying on delegation of authority while he is preoccupied with pleasure or worship." This implies several important things. First, the Caliph is ultimately responsible for what occurs in his domains, thus he must be personally involved in their day-to-day affairs. Second, he rules not only on God's behalf, but also on behalf of his fellow Muslims and other subjects, making it attendant upon him to know the "conditions of the people." Third, this management of public policy and protection of the faith are to take absolute priority over his own personal good, whether the mundane good of pleasure or the sacred good of worship. ${ }^{5}$

Māwardī's description of these ten caliphal duties can be used to further either despotic or constitutional ends. If one considers that the Caliph does 
not rule by hereditary right, but by the will of God and the expressed will of electors, and that his duties to guard the faith and the faithful supersede his prerogatives for personal pleasure, then what emerges is a system which accommodates itself to the political realities on the ground, while simultaneously mustering all the gentle and not so gentle reminders of the duties and obligations of rule that it can. ${ }^{6}$ All of these are marshaled in the effort to ensure that the overarching good of Muslim unity and purity of faith are maintained at virtually any cost. ${ }^{7}$

What happens when the essential duties of the caliph are not fulfilled is perhaps the central question that stems from this relationship between sociopolitical power and faith. Some scholars argue that Māwardī simply uses his book to make concessions to political realities in which caliphs were dominated by amirs (princes or sultans) who demanded that they be recognized as legitimate rulers under various forms of duress, including imprisonment and armed force. ${ }^{8}$ In the third chapter of The Ordinances of Government, Māwardī goes to the absolute logical extreme of his argument that political power requires religious legality without exception. Writing about a governor who has declared himself an independent ruler of a province, he says:

By seizing power, the governor becomes an independent and exclusive controller of political matters and administration, while the Caliph, by his permission, becomes the implementer of the dictates of religion, thus transforming unlawfulness into legality, and the forbidden in the legitimate... Thus, decisions that would normally be unacceptable in regular appointment based on choice are permissible under usurpation and necessity . . .

Commentators like Gibb are highly critical of this argument, saying that "Necessity and expediency may indeed be respectable principles, but only when they are not invoked to justify disregard of the law." ${ }^{9}$ Of course, that begs the question what is meant by "disregard of the law." If one means the principle of rule of law, in the sense that a constitutional regime of any sort should have laws which equally apply to all citizens and which cannot be arbitrarily enforced or changed, then Māwardī's concession is a clear violation of this principle. However, if one takes the sharīa to be the only true law, and if that law requires the unity of the Muslim populace and the religious legitimacy of whoever rules them, then nothing can be truly legal in the absence of this Muslim legal Grundnorm. It is commonly accepted that much of the Medieval Sunni political writing was actually an effort to find this thread of legitimacy in events that provided it with stark challenges, all in order to preserve the "dogma of divine guidance of the community and the infallibility of its ijma ('My community will never agree upon an error')." ${ }^{10}$

In some ways, this search for legality in the midst of turmoil simply reflects the conflation of sacred and secular in the classical Muslim state and bears much resemblance to Christian theological discussions that try to 
make sense of a world in which God is sovereign and just, yet which is also full of warring human sovereigns who may perpetrate all manner of injustices. The Caliph's role as guarantor of religious law and political legitimacy makes the Christian solution of separating these roles difficult, but as Māwardī's list of duties reveals, it is by no means impossible in practice. In a direct rebuff to Gibb and Lambton's portrayal of Māwardī as an apologist for usurpation, Hamid points out that he actually placed a variety of conditions on the acceptance of the usurping regime. Since political revolutions don't typically happen in well-run and well-defended states, the very fact that the coercive regime has risen up indicates that there were already significant problems with the previous regime. Furthermore, sheer military power will not suffice to maintain political power in the long term. "Power has always to be transferred into authority." This authority derives from the just and effective administration of the state and ultimately brings about the desired unity of Muslims and the ability for people to observe religious requirements that are the bases of Māwardī's conception of the state. ${ }^{11}$

The process that Māwardī describes in this contentious section of The Ordinances is therefore one in which the sultan or amir and the Caliph have symbiotic roles to play in legitimizing power on the one hand, and exercising it on the other. This division is reflected in his mention of two kinds of mosques and the importance of Friday prayers in particular falling under the purview of the state. Calder relates that "He distinguishes between the post of prayer leader in relation to communal prayer, Friday prayer and supererogatory prayer":

The appointment of an imam to lead the communal prayer is dependent on the type of mosque in which prayer is held. There are two types: masdjid sultdniyya and masdjid 'dmmiyya [government mosques and public mosques]. The sultdniyya mosques are those ... for the supervision of which the sultan is responsible. No-one may be appointed (intiddb) to the imamate [in such a mosque] except one appointed (nadab) and invested (qallad) by the sultan ... Once someone has been invested [in a post] he has more right than any other to lead the prayer even if others are better or more knowledgeable than he. ${ }^{12}$

Thus, in Māwardī's formulation of the rule of law, even in its cosmic sense, all social practices, even those which are part of the Five Pillars of Islam, must be stamped with the worldly legitimacy of the caliphal institution in order to be valid. Ironically, this rather dogmatic assertion of the sultan's ultimate authority to appoint imams, and the further insistence that they be given priority over any other prayer leader in a given mosque is meant to cut through the inevitable disputes as to the proper conduct of prayer depending upon which school of figh one subscribed to. Again, the immediate aim of unity and peace within a Muslim state took priority over sorting out doctrinal disputes. This end justified the means of achieving it, even if those means amounted to little more than despotism. Here we have yet another odd reverse echo of Machiavelli, as will be discussed in more 
detail later, in which both men argue that preventing religious disputes and overseeing worship are essential in effective and lasting leadership, yet do so for diametrically opposed reasons, with Māwardī making his case to preserve the requirements of shari ${ }^{\top} a$, and Machiavelli focusing squarely on the preservation of the power of "the prince."

Māwardī's vision of power is one which permeates every layer of society and one in which that power itself is permeated with the divine, the execution of divine commands and the prevention of what is divinely forbidden. This sacred rule of law is one which is primarily concerned with maintaining the unity of the House of Islam, even if that unity is purely nominal, and which seeks to subvert doctrinal disputes so that a unified Muslim people can more effectively spread their message and live out their faith. Ira Lapidus nicely sums up Māwardī's work (and that of similar thinkers), arguing that it is "a theory of the caliphate that symbolized the ideal existence of the unified umma, while at the same time allowing for historical actualities ... the state was not a direct expression of Islam but a secular institution whose duty it was to uphold Islam." ${ }^{13}$

\section{Machiavelli's Mirror-Principally about the Prince, not the Principality}

In comparing the political writings of Māwardī and Machiavelli, it is essential to consider their audiences as well as their central values. Both men were indeed writing for rulers and are clearly keen to please their ruling readers. Both of them are notoriously comfortable with justifying whatever state of affairs and whatever regime happens to be in ascendency. However, there are several equally, and perhaps more, important differences between them. Whereas Māwardī was writing a jurisprudential treatise on rule, not only to a particular Caliph, but to the Muslim community as a whole with the ever-present aim of preserving at least a pretense of unity in the House of Islam, Machiavelli is writing from a hopelessly fractured Italy in a recently conquered Florence.

Although there was a strong religious ideal of a unified Christendom, it had been roughly a thousand years since the fall of Rome and the idea of a unified Christian polity. That Machiavelli has no concern for Christian unity, is thus somewhat of a non-issue. ${ }^{14}$ However, if one considers Māwardī's focus of unity outside of its specific Muslim context, it could be seen to be part of the ancient concern for the common good. This criterion then is a legitimate target for comparison and consideration. Did Machiavelli betray any concern for the good of the people or the state as a community? If so, is it systematized or institutionalized in any way, or is it completely intertwined with the person of the Prince? Once these questions are addressed, it may then be possible to draw larger comparisons about the ways that Māwardī and Machiavelli approach power, how these approaches may reflect their historical and cultural contexts, and what application they may have to present political concerns. 
First, Machiavelli's motivation and stated objectives deserve a quick examination. Where Māwardī was seeking to describe the proper relationship between the religious sovereignty of the Caliph and the de facto sovereignty of the sultans, ${ }^{15}$ Machiavelli wrote The Prince as a gift of wisdom to pass along to the new Medici ruler of Florence. In his dedication, he says the following:

I hope it will not be considered presumptuous for a man of very low and humble condition to dare to discuss princely government, and to lay down rules about it. For those who draw maps place themselves on low ground, in order to understand the character of the mountains and other high points, and climb higher in order to understand the character of the plains. Likewise, one needs to be a ruler to understand properly the character of the people, and to be a man of the people to understand properly the character of the rulers. ${ }^{16}$

As this passage shows, Machiavelli is also writing a book about the art of governing, but it is explicitly princely government and there is no mention of any other institution or community values. A brief glance at his chapter headings also shows that he undertakes his task, like Māwardī, by defining various types of regime, different ways of gaining power, and by explaining different methods which are thus best suited to maintaining power. ${ }^{17}$ Before looking at the views represented in The Prince in more detail, it is essential to note that other works in Machiavelli's corpus, such as The Discourses, are emphatically more interested in institutionalism and constitutionalism. For example, in writing on "Of How Many Species Are Republics," he cites the examples of Sparta and Athens as cities which had strong law-givers who endowed them with a sense of identity and with a concern for maintaining the common good through institutional government, but only Sparta offered a mixed constitution in his view, which meant that the Athenian democracy was needlessly short-lived and unstable. This is an inherently traditional argument in favor of mixed constitutionalism in which monarchy, aristocracy, and democracy are carefully balanced so as to avoid their undesirable corollaries of tyranny, oligarchy, and mob rule. After giving a cyclical account of the rise, fall, and renewal of republics that is highly reminiscent of thinkers like Ibn Khaldun with its focus on a gradual loss of concern for the common good and various types of creeping licentiousness, he notes that this cycle could go on indefinitely were it not for the existence of other states which, if more stable and better run, may very well take over and rule weak and unstable states. From this historical cycle, he derives a principal that all modes of government

... are pestiferous because of the brevity of life in the three good ones, and because of the malignity in the three bad. So those who prudently order laws having recognized this defect, avoiding each of these modes by itself, chose one that shared in all, judging it firmer and more stable; for the one guards the other, since in one and the same city there are the principality, the aristocrats, and the popular government. ${ }^{18}$ 
Although Machiavelli is arguably as centrally concerned with stability as ever, The Prince stands in stark contrast to this other work with its laser-like focus on the person of the Prince and the lack of discussion of his relations with other state organs or institutions. Rather than undertake such an account, Machiavelli devotes chapter 8 of his text to a discussion of "Those who become rulers through wicked means," just as Māwardī has a section in his book regarding those who have usurped power, rebelled against the legitimate power, or have otherwise undertaken some type of coup d'état. This brief chapter is primarily a discussion of two historical cases in which rulers have come to power through deeds which are universally agreed to be immoral and despicable. In the ancient world, the example of Agathocles and his domination of Syracuse is used to show how a man who was of low social class rose to kingship by conspiring with enemy troops, murdering the Syracusan Senate, and then betraying and terrifying his erstwhile Carthaginian allies into allowing him complete autonomy. Although some commenters see this passage as one which distinguishes criminality from virtue, Kahn finds it one of the most disturbing passages in the entire book. She writes that it strips the concept of virtue of any moral meaning and instead defines it as "a faculty of deliberation about particulars" that allows a ruler to adjust his actions and character to what is demanded by the times. ${ }^{19}$

The second story Machiavelli tells in chapter eight is much more contemporary and relates how Oliveretto of Fermo destroyed the "free institutions" of Fermo, setting himself up as ruler instead, by outrageously murdering his uncle who had raised him, massacring all the leading citizens of the city who might oppose his rule, and intimidating the judges into submission. ${ }^{20}$ Again, this story shows his reader that there is nothing conventionally moral, virtuous, or even fortunate in the rise of this man. Indeed, his later death by strangulation after being deceived by Cesare Borgia is duly related. One may be tempted to think it is thus a cautionary tale, but Machiavelli seems to mention it as a matter of simple misjudgment rather than any kind of divine retribution. He then poses the obvious question that these stories raise: "how could it happen that Agathocles, and others like him, after committing countless treacherous and cruel deeds, could live securely in their own countries for a long time, defend themselves against external enemies and never be plotted against by their citizens?" 21 This question is important because writers ranging from Cicero in his De Oficiis to Machiavelli's contemporary Renaissance humanists stressed the cultivation of moral excellence in princes, and strongly cautioned their readers that lacking these qualities would lead to their demise. ${ }^{22}$

On the contrary, like Māwardī, Machiavelli seems acutely aware that the road to power often looks nothing like the ideal roadmap laid out in other less realistic texts. Although he too could be accused of being an apologist for the worst kinds of despots, this passage seems to betray an implicit concern that goes beyond the calculated cynicism portrayed in his 
introduction; namely, he wants stability. After all the wars and revolutions and regime changes, it seems that even the most able and cunning public servant tired of the intrigue and unsettling need to switch allegiances at great personal risk. The chapter concludes then with an unexpected answer to his earlier question. Criminal men can come to power through evil means, and maintain that power for a considerable length of time not because criminality is good or even necessary, but because they committed their criminal deeds well. This requires further explanation of course, and Machiavelli gladly explains something which may indeed have genuine wisdom. Well-committed evil deeds are "all committed at once, because they are necessary for establishing one's power, and are not afterwards persisted in, but changed for measures as beneficial as possible to one's subjects." ${ }^{23}$ In this simple sentence Machiavelli's veil of cynicism drops and he betrays yet another moral concern that the ruler act in a way that is "as beneficial as possible" to his subjects. Although this may be seen as a weak injunction given that these benefits are not defined or institutionalized, it can equally be seen as an extremely high moral bar for a political actor to meet because he must rise to power through an unwavering self-regard, yet maintain that power through a focus on those below him.

This passage also shows another very striking similarity to Māwardī's earlier work. Both of these thinkers acknowledge that rulers can come to power through means that are entirely illegitimate, yet both of them argue that that power can only be maintained by a ruler who subsequently gains legitimacy by stable and effective rule. If their criminality continued, these rulers would face their own rebellions and likely be overthrown. Therefore, it seems that the moral values required of a leader apply only once that leader has actually consolidated power and thus gained authority.

\section{Conclusions}

The concluding lines of Machiavelli's The Prince are as stirring and grandiose as his opening lines are craven and shamelessly self-promoting. He writes:

The opportunity to provide Italy with a liberator, then, after such a long time, must not be missed. I have no doubt at all that he would be received with great affection in all those regions which have been inundated with foreign invasions, as well as with a great thirst for revenge, with resolute fidelity, with devotion and tears of gratitude... Let your illustrious family, then, take up this mission, with the spirit and courage and the faith that inspires all just causes, so that under your standard our country may be ennobled . . ${ }^{24}$

These words confirm that although his desires have little or nothing to do with the religious nature of his state, Machiavelli desired unity just as Māwardī did. His umma was simply the Italian nation, not all Christendom, 
but it was nonetheless the identity to which he obviously clung most closely. Rather than criticizing these thinkers as apologists for tyranny then, perhaps their work simply reflects the extreme duress of the political circumstances they found themselves in, and the correspondingly extreme desire for peace and stable government, which they seem to view as always preferable to instability and war.

Pluralistic politics faces a variety of challenges. On the one hand, regimes must typically at least pretend to care about human rights and other universalist humanitarian values in line with the UN Charter and related documents. On the other hand, there is an increasing recognition that localized forms of governance and recognition of local values, such as religious heritage, clothing that is deemed appropriate in its context, and traditional social institutions involving clergy, elders, or others who may not be official government functionaries, are also fundamental human rights. How then can the tension between these competing demands be relieved, and what do Māwardī and Machiavelli's works have to say about them?

One could argue that both writers are explicitly bound to their own contexts. It is certainly true that they faced unique circumstances and that the lessons they derived from them cannot be fully translated to present-day issues. However, it is also true that both of them saw their work as containing elements of timeless wisdom. In Māwardī, it is the wisdom of the eternal rule of law as defined by shari ${ }^{`}$ a and facilitated by a Muslim ruler in an Islamic institutionalized state. For Machiavelli, it is the wisdom of historical experience, a rejection of idealism when it leads to the greater evil of instability, and the very modern call to create a national consciousness and a nationalistic, unified Italian polity.

Perhaps one of the best reasons to juxtapose these two particular thinkers lies in the way it embodies the tension between sectarian and secular visions of power that persist in many layers of government throughout the world. If one looks at Māwardī's vision of governance as a structure apart from its Islamic roots, it reveals an institutionalized approach to legitimacy in which a particular normative aim must reign supreme and in which those who govern must be aware of and responsive to the conditions of those whom they govern. This system could easily be adapted to promote liberalism, Christian fundamentalism, Hindu nationalism, or any number of political or theological schools of thought. At first glance, its emphasis on the divine or revealed institutions like the Caliphate may seem ill-suited to such a task, but it should be noted that humanists are often just as anthropocentric and likely to appeal to God-given, universal, or inalienable human rights, which serve a similar rhetorical function as an appeal to an undeniable fundamental truth. History shows that virtually every group making such normative truth claims has been willing to fight to defend and expand their spheres of influence. Whether calling it regime change, a 
crusade, taking back one's country, or jihad, the essential goal of "conversion or signing a treaty of subjection," remains in play. ${ }^{25}$

Conversely, Machiavelli's personalized view of power on display in The Prince, seems timely given the rise of populist nationalists in a context of globalization and sometimes imperialistic superpowers, international institutions and multinational corporations. This impulse, on display in cases like the presidency of Rodrigo Duterte in the Philippines, the electoral successes of far right movements like France's National Front and Germany's Alternative for Germany, and the rise of Donald Trump in the United States, illustrates the continuing appeals of stability and national pride, a simultaneous affirmation of identity and rejection of the other. Furthermore, these desires are channeled through charismatic leaders who can embody the state, articulate social fears and grievances, and act as a focal point for people's political aspirations.

Whether considering the horrible conundrums at the heart of the unrest in Egypt after the overthrow of President Morsi's government, or the ongoing resonance of post-colonial language in Zimbabwe, or the otherwise inexplicable alliances between such odd bedfellows as Venezuela, a deeply Catholic South American state plagued by corruption and murder, and Iran, a devoutly and explicitly Islamic Shiite state intent on spreading its brand of Islam, the need to reconcile admirable ideals and constitutional principles with very ugly political realities continues unabated. Perhaps, as Machiavelli suggests, it is ultimately kinder for rulers to use brutality to consolidate power if the alternative is an anarchic vacuum. Of course, this operates on the extremely tenuous assumption that said brutality does not plant the seeds of historical grievance that can lead to still worse violence and unrest if the government is ever again confronted with genuine challenges to its legitimacy and maintenance of control. ${ }^{26}$

Alternatively, rather than leading those who are oppressed in these regimes to simply accept and obey the status quo, Māwardī and Machiavelli also present an opportunity to remind these leaders that their authority is proportional to their effectiveness and fairness. People may very well be able to overlook the way someone or some group comes to power, if once in power they prove to be just and effective. Japan, for example, still lives under the constitution dictated to it by the victorious Allied powers after the end of World War II. However, regimes in which the aspirations and needs of all the people are not acknowledged do indeed seem doomed to fail, which the fall of regimes as disparate of those of Pinochet, Morsi, and Gaddafi shows.

Notes

1 - Antony Black, The West and Islam: Religion and Political Thought in World History (Oxford: Oxford University Press, 2008), p. 6. 
2 - This is not to argue that Māwardī's ideal Caliphate shares its primary aim, which was to guard the faith of Islam, with those of the EU and $\mathrm{UN}$, which are non-sectarian and instead tend to speak in the language of humanism and liberal democracy.

3 - Ali ibn Muhammad Māwardī, The Ordinances of Government: A Translation of Al-Ahkam Al-Sultaniyy W' Al-Wilayat Al-Diniyya, trans. Wafaa Hassan Wahba (Reading: Garnet, 1996), p. 16.

4 - Abd al-Hakeem Carney, "The Desacralisation of Power in Islam," Religion, State \& Society 31 (2) (2003): 205.

5 - Although some might see the injunction to avoid delegating authority in knowing the conditions of the people and managing policy as despotic, this must be seen in the context of all the Caliphal duties. The preceding ninth duty makes it abundantly clear that the Caliph must rely on and appoint public servants of good character and that they will in some sense act on his authority. However, unlike a true despotism where the leader sets the standards of what is good or virtuous, and so can escape accountability when things go wrong by scapegoating those beneath them, Māwardī's Caliph is accountable for whatever the government does in his name. Furthermore, that accountability is twofold, existing on behalf of the people whose good he is supposed to protect, and on his duty to uphold God's divine law.

6 - The fact the Caliphate was not a hereditary institution in the mold of a European monarchy should not preclude the fact that the office was only available to male Muslims from the Quraysh tribe and did change hands from father to son on a number of occasions. Still, the lack of explicit rules for transferring power and the relatively large pool of eligible candidates led to the potential for both more freedom in appointing a ruler and more possible unrest as various aspirants jockeyed for power. For further information on the historical Caliphate, see Ahl al-Bayt, "Abbasid Caliphate (749-1258) Barmakids as chief viziers of 80 hereditary succession of 87-88 al-Mamun (r. 813-833) 70, 80-81, 127 al-Mansur 70, 127." al-Andalus 106 (2015): 107. Also, Gerald R. Hawting, The First Dynasty of Islam: The Umayyad Caliphate AD 661-750 (Routledge, 2002).

7 - This even includes conditions under which a usurper caliph can legitimately be installed once his predecessor is shown to be no longer capable of exercising his office. See Māwardī (1996), pp. 20-21.

8 - For example, Hamilton Alexander Rosskeen Sir Gibb, William Roe Polk, and Stanford Jay Shaw, Studies on the Civilization of Islam ... Edited by Stanford J. Shaw and William R. Polk (London: Routledge \& Kegan Paul, 1962), pp. 162-164. 
9 - Studies on the Civilization of Islam ... Edited by Stanford J. Shaw and William R. Polk (London: Routledge \& Kegan Paul, 1962), p. 164.

10 - Studies on the Civilization of Islam ... Edited by Stanford J. Shaw and William R. Polk, pp. 154-155.

11 - Eltigani Abdulqadir Hamid, "Al-Mawardi's Theory of State: Some Ignored Dimensions," American Journal of Islamic Social Sciences 18 (4) (2001): 8-9.

12 - Norman Calder, "Friday Prayer and the Juristic Theory of Government: Sarakhsī, Shīrāzī, Māwardī," Bulletin of the School of Oriental and African Studies 49 (1) (1986): 44.

13 - Ira M. Lapidus, "The Golden Age: The Political Concepts of Islam," Annals of the American Academy of Political and Social Science 524 (1992): 16.

14 - Although various writers, including Shakespeare, have accused Machiavelli of being irreligious or heretical, there is an alternative view that he was highly moral, but that his morals were informed primarily by the experiences of Classical history and philosophy rather than Christianity. See, for example, J. Samuel Preus, "Machiavelli's Functional Analysis of Religion: Context and Object," Journal of the History of Ideas 40 (2) (1979).

15 - Nazih Ayubi, Political Islam: Religion and Politics in the Arab World (Routledge, 2004), pp. 24-25.

16 - Niccolò Machiavelli, Quentin Skinner, and Russell Price, Machiavelli, Cambridge Texts in the History of Political Thought (Cambridge; New York: Cambridge University Press, 1988), p. 4.

17 - Dietz offers an intriguing and provocative alternative, which is that Machiavelli purposely sought to mislead Lorenzo de Medici and to encourage him to undertake highly dangerous activities that would bring about his downfall. This paper, however, takes Machiavelli at face value and analyses his words as though he actually meant them. For more, see Mary G. Dietz, "Trapping the Prince: Machiavelli and the Politics of Deception," The American Political Science Review 80 (3) (1986).

18 - Niccolò Machiavelli, Discourses on Livy (University of Chicago Press, 2009), pp. 10-13.

19 - Victoria Kahn, "Virtù and the Example of Agathocles in Machiavelli's Prince," Representations 13 (1986): 68-71.

20 - Machiavelli, Skinner, and Price, Machiavelli, pp. 32-33.

21 - Machiavelli, 33. 
22 - Quentin Skinner makes a point of noting the various ways that Machiavelli directly and knowingly contradicts this work. For instance, where Cicero advises a ruler "to banish fear and cleave to love," Machiavelli says it is better to be feared than loved. Cicero also says a ruler must keep his word as a matter of honor, whereas Machiavelli says he should never keep a promise if it is against his own interests. (See The Prince, Chapter 15). Quentin Skinner, "Machiavelli's Political Morality," European Review 6 (3) (1998): 323.

23 - Machiavelli, Skinner, and Price, Machiavelli, 33.

24 - Machiavelli, 91.

25 - Ali ibn Muhammad Māwardī, The Ordinances of Government: A Translation of Al-Ahkam Al-Sultaniyy W' Al-Wilayat Al-Diniyya, trans. Wafaa Hassan Wahba (Reading: Garnet, 1996), p. 16.

26 - The case of Syria and Assad's arguably Machiavellian approach to maintaining power seems illustrative of the potential for explosive blowback from brutality exercised in the name of stability.

\section{References}

al-Bayt, Ahl. 2015. "Abbasid Caliphate (749-1258) Barmakids as chief viziers of 80 hereditary succession of 87-88 al-Mamun (r. 813-833) 70, 80-81, 127 al-Mansur 70, 127."al-Andalus 106.

Ayubi, Nazih. 2004. Political Islam: Religion and Politics in the Arab World. Routledge.

Black, Antony. 2008. The West and Islam: Religion and Political Thought in World History. Oxford: Oxford University Press.

Calder, Norman. 1986. "Friday Prayer and the Juristic Theory of Government: Sarakhsī, Shīrāzī, Māwardī." Bulletin of the School of Oriental and African Studies 49, no. 1:35-47.

Carney, Abd al-Hakeem. 2003. "The Desacralisation of Power in Islam." Religion, State \& Society 31, no. 2:203-219.

Dietz, Mary G. 1986. "Trapping the Prince: Machiavelli and the Politics of Deception." The American Political Science Review 80, no. 3:777-799.

Gibb, Hamilton Alexander Rosskeen Sir, William Roe Polk, and Stanford Jay Shaw. 1962. Studies on the Civilization of Islam . . . Edited by Stanford J. Shaw and William R. Polk. London: Routledge \& Kegan Paul.

Hamid, Eltigani Abdulqadir. 2001. "Al-Mawardi's Theory of State: Some Ignored Dimensions." American Journal of Islamic Social Sciences 18, no. 4:1-18. 
Hawting, Gerald R. 2002. The First Dynasty of Islam: The Umayyad Caliphate AD 661-750. Routledge.

Kahn, Victoria. 1986. "Virtù and the Example of Agathocles in Machiavelli's Prince." Representations 13: 63-83.

Lapidus, Ira M. 1992. "The Golden Age: The Political Concepts of Islam." Annals of the American Academy of Political and Social Science 524: 13-25.

Machiavelli, Niccolò. 2009. Discourses on Livy. Edited and translated by Harvey Mansfield and Nathan Tarcov. Chicago: University of Chicago Press.

- Quentin Skinner, and Russell Price. 1988. The Prince. Cambridge Texts in the History of Political Thought. Cambridge; New York: Cambridge University Press.

Mawardī, Ali ibn Muhammad. 1996. The Ordinances of Government: A Translation of Al-Ahkam Al-Sultaniyy $W^{\prime}$ Al-Wilayat Al-Diniyya. Translated by Wafaa Hassan Wahba. Reading: Garnet.

Preus, J. Samuel. 1979. "Machiavelli's Functional Analysis of Religion: Context and Object." Journal of the History of Ideas 40, no. 2:171-190.

Skinner, Quentin. 1998. "Machiavelli's Political Morality." European Review 6, no. 3:321-325. 